Exp. Anim. 35 (2), 165-167, 1986

\title{
The Influence of Age on the Number of Non-atretic Follicles Classified according to Follicular Size in the Rat Ovary
}

\author{
Satosi KAGABU \\ Laboratory of Veterinary Reproduction, Faculty of Agriculture, \\ Yamaguchi University, Yamaguchi-shi Yoshida, 753, Japan
}

(Received 13 August 1985/Accepted 4 December 1985)

\begin{abstract}
The age-related changes in the number of follicles classified according to size were investigated. The number of large follicles expected to ovulate spontaneously was not influenced by age, though the number of small follicles $250-549 \mu \mathrm{m}$ in diameter, recovered by PMSG and hCG, was not constant. There was no relationship between the number of large follicles and small ones. This study suggests that the variation in ovum count after superovulation depending on age may be based on the variation in the number of small follicles.
\end{abstract}

The number of ova shed after superovulation in adult rats is influenced by age [1]. It was shown that non-atretic follicles measuring $250-549 \mu \mathrm{m}$ in diameter were expected to ovulated by superovulation treatment [1], and that follicles larger than $549 \mu \mathrm{m}$ seen at the proestrus ovulate in response to an $\mathrm{LH}$ surge in the intact adult rat $[2,3,4]$.

In a previous report [7], the ability of the rat to induce superovulation was not made clear as regards ovarian follicular size with age. The purpose of the present study is to determine the changes in the number of nonatretic follicles measuring 250-549 $\mu \mathrm{m}$ and greater than $549 \mu \mathrm{m}$ from two to 78 weeks.

\section{Materials and Methods}

The 220 rats employed in this study were those of the virgin Wistar-Imamichi strain, two to 78 weeks of age. They were maintained under $24 \pm 2^{\circ} \mathrm{C}$ with 14 -hour illumination in 24-hours (lights on at $7 \mathrm{a} . \mathrm{m}$.). The stage of estrous cycles was determined by daily vaginal smears taken around 10 a.m. Animals showing at least two consecutive four-day estrous cycles were used, excluding immature rats.
They were fed chow and water ad libitum because a restricted diet results in a lack of follicular growth [5].

Experiment 1. The relationship between age and the number of large non-atretic follicles expected to ovulate by spontaneous ovulation.

The mature animals were autopsied at 5 p.m. on the day of proestrus, and the immature rats were at $5: 00$ p.m. every week. The ovaries were removed and fixed for 24 hours in Lavdovsky's fluid. The tissues were dehydrated and embedded in paraffin, using standard histological procedures. Complete serial sections, $15 \mu \mathrm{m}$ in thickness, were prepared for each ovary. The sections were mounted and stained with Mayer's hematoxylin and eosin solution. All sections of each ovary were examined and all follicles displaying a nucleous of an oocyte were measured using a micrometer under microscope. Follicles showing evidence of atresia were excluded from this study according to the criterion described by Braw and Tsafriri [6]. Follicles measuring 250-549 $\mu \mathrm{m}$ and greater than $549 \mu \mathrm{m}$ in average diameter were respectively calculated.

Experiment 2. The relationship between age and the number of non-atretic follicles 


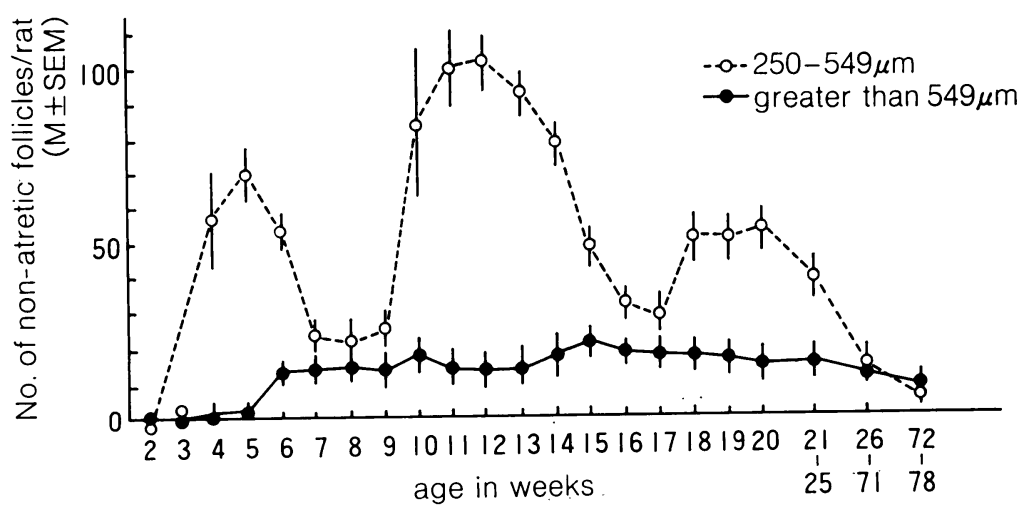

Fig. 1. Changes in the number of non-atretic follicles with age. Each point represents 10 rats.

expected to ovulate by superovulation treatment.

The mature animals were autopsied at 11 a.m. on the day of metestrus. In this series, immature rats were also killed at 11:00 a.m. every week. Non-atretic follicles 250-549 $\mu \mathrm{m}$ in average diameter were observed by the procedure of experiment 1 .

The results were analyzed by the F-test.

\section{Results}

Figure 1 shows the relationship between number of non-atretic follicles per rat and age in weeks. At the age of two to three weeks, none of the rats had non-atretic follicles greater than $549 \mu \mathrm{m}$ in average diameter. The number of follicles increased to $13.5 \pm 3.1$ at six weeks, and the level remained unchanged up to 52 weeks of age. The maximum follicle score was $20.0 \pm 2.6$ at 15 weeks.

The average number of non-atretic follicles $250-549 \mu \mathrm{m}$ in size showed three peaks at 5 , 12 and 20 weeks. The number of large follicles greater than $549 \mu \mathrm{m}$ was not related to that of small ones.

\section{Discussion}

An age-related decline in the number of oocytes or follicles has been reported by Arai [7], Mandl and Zuckerman [8, 9] and Mandl and Shelton [10], but there is no study concerning the number of follicles expected to ovulate. There are two types of ovulation; one is spontaneous ovulation, and the other is superovulation.

In the case of spontaneous ovulation, the non-atretic follicles greater than $549 \mu \mathrm{m}$ were considered to ovulate by morphometrical examination $[2,3,4]$, while in superovulation, the non-atretic follicles $250-549 \mu \mathrm{m}$ in size may finally ovulate [1].

Therefore, the investigation must clarify age-dependent changes in individual follicular size, because the response to gonadotropin varies with follicular size.

In this study, rats were autopsied at 11 a.m. on the day of metestrus because PMSG was injected for superovulation. On the other hand, in the study concerning spontaneous ovulation, rats were killed at 5 p.m. on the day of proestrus because the LH surge occurs between $5: 30-9: 00 \mathrm{pm}$ [11].

In rats of six to 26 weeks in age, the number of non-atretic follicles greater than 549 $\mu \mathrm{m}$ in size remained from 13.5 to 20.0 on average. This suggests that the number of follicles expected to ovulate is constant after six weeks of age in rats.

On the other hand, the number of nonatretic follicles $250-549 \mu \mathrm{m}$ was not constant, showing three peaks. There was no relationship between the number of small (250-549 $\mu \mathrm{m}$ ) and large (greater than $549 \mu \mathrm{m}$ ) follicles at any age.

The present results confirmed the significance of age in the number of follicles measuring $250-549 \mu \mathrm{m}$. The number of non-atretic 
follicles shows different response toage according to follicular size.

Therefore, the variation in ovum count after superovulation depending on age may be based on the variation of the follicles 250-549 $\mu \mathrm{m}$ in size.

\section{References}

[1] Kagabu, S. (1983). Morphometrical study on the relationship between number of follicles and number of ova shed in superovulation treated adult rats. Jpn. J. Fert. Ster., 28, 505-507.

[2] Mandl, A. M., and Zuckerman, S. (1952). Cyclical change in the number of medium and large follicles in the adult rat ovary. J. Endocrinol., 8, 341-346.

[3] Hashizume, K., Sugawara, S., and Takeuchi, S. (1975). The follicular development and oocyte maturation with special reference to the release of ovulating hormone in post-partum rats. Jpn. J. Anim. Reprod., 21, 28-36.

[4] Hashizume, K., Sugawara, S., Takeuchi, S., and Masaki, J. (1971). Follicular development and oocyte maturation in rats just before and after parturition induced by prostaglandin $\mathrm{F} 2 \alpha$. Jpn. J. Anim. Reprod., 23, 148-152.

[5] Husely, R. A., and Ball, Z. B. (1945). A study of the genesis of histological changes produced by caloric restriction in portions of the endocrine and reproductive systems of strain a female mice.Anat. Rec., 92, 135-155.

[6] Braw, R. H., and Tsafriri, A. (1980). Effect of PMSG on follicular atresia in the immature rat ovary. J. Reprod. Fert., 56, 267-272.

[7] Arai, H. (1920). On the postnatal development of the ovary (albino rat), with special reference to the number of ova. Amer. J. Anat., 27, 405-462.

[ 8 ] Mandl, A. M., and Zuckerman, S. (1951). The relationship of age to numbers of oocytes. $J$. Endocrin., 7, 190-193.

[9] Mandl, A. M., and Zuckerman, S. (1951). Numbers of normal and atretic oocytes in unilaterally spayed rats. J. Endocrin., 7, 112-119.

[10] Mandl, A., and Shelton, M. (1959). A quantitative study of oocyte in young and old multiparous laboratory rats. J. Endocrin., 18, 444-450.

[11] Kagabu, S., and Umezu, M. (1984). The inhibition of LH discharge by pentobarbital administration in adult rats priming with PMSG. Jpn. J. Fert. Ster., 29, 279-282.

\title{
ラット非閉鎖卵胞数の加歯に伴う，大きさ別消長
}

\author{
利 部 聰 \\ 山口大学農学部獣医学科家畜臨床繁殖学教室
}

ラット卵胞を大きさ別に分類して，加齢に伴う消長を 調べた。自然排卵に至ると思われる $550 \mu \mathrm{m}$ 以上の卵胞 の数は, 加齢に伴ってほとんど変化はみられないが, 過 排卵誘起処理によって排 卵に至ると思われる 250〜549 $\mu \mathrm{m}$ の卵胞の数は，加柃によって影響されると指摘され た。後者の変化は過排卵処理後にみられる排卵数の変異 の 1 要因と考えられる。 